\title{
PENGGUNAAN KNOW WHAT LEARNED (K-W-L) STRATEGY UNTUK MENINGKATKAN KEMAMPUAN SISWA MEMBACA REPORT TEXT
}

\author{
USING KNOW WHAT LEARNED (K-W-L) STRATEGY \\ O INCREASE STUDENTS'READING ABILITY \\ OF REPORT TEXT
}

ATIK ZULAIKAH

SMAN57 Jakarta

Received: May 10, 2021

Revised: May 13, 2021

Accepted: May 21, 2021

\begin{abstract}
This study aimed at investigating the improvement of the students' reading ability of the report text through K-W-L strategy at the grade XI of high school/eve/ in IPA Class. The participants were 36 students and they were chosen through purposive sampling technique. The instrument consists of test and non-test. Test instrument is multiple choice and consists of 20 items. Non test instrument is observation sheet. Data collecting techniques were carried out by giving written test and observation sheets. The data analysis procedure based on the cycles. From the research result, it was found that the learning outcomes of student's knowledge increase in cycle I completeness by $74,14 \%$. In cycle II, completeness became $83,06 \%$. The assessment of students 'skill has increased in the first cycle of completeness to $66,65 \%$. Cycle II completeness $83,32 \%$ there is improvement $16,67 \%$ it means that the improvement of learning due to K-W-L strategy. Based on this research, it can be concluded that $K-W-L$ strategy can improve reading capability in report text.
\end{abstract}

\begin{abstract}
Abstrak.
Penelitian ini bertujuan meningkatkan kemampuan membaca teks ilmiah dengan menggunakan Strategi K-W-L (Know-What-Learned) pada siswa SMA kelas XI IPA. Partisipan penelitian ini berjumlah 36 siswa dipilih menggunakan teknik purposive sampling. Instrumen penelitian terdiri atas terdiri atas tes dan non-tes. Adapun instrumen tes berupa pilihan ganda yang berjumlah 20 item. Sedangkan instrumen non-tes lembar pengamatan. Prosedur pengumpulan data melalui pemberian tes tertulis dan pengamatan. Prosedur analisis data berdasarkan siklus (di setiap akhir siklus). Temuan penelitian menunjukkan bahwa hasil tes tentang kemampuan menulis siswa diperoleh nilai rata-rata siklus I sebesar 74,14 hasil rata-rata siklus II sebesar 83,06 hasil tersebut menunjukkan kenaikan sebesar 8,92 point dari siswa yang tuntas belajar pada siklus I 66,65\% dan pada siklus II siswa yang tuntas belajar sebesar 83,32\% terjadi kenaikan sebesar 16,67\% berarti hasil belajar siswa dapat meningkat, dengan menggunakan strategi pembelajaran K-W-L. Hasil dari kedua siklus ini didukung oleh data hasil pengamatan selama proses penelitian berlangsung. Berdasarkan hasil penelitian tersebut dapat disimpulkan bahwa strategi $K-W-L$ dapat meningkatkan hasil belajar siswa pada Aspek Membaca Report Text.
\end{abstract}

Keywords: $\quad$ K-W-L Strategy, report text, reading ability

Kata kunci: $\quad K-W-L$ strategy, teks laporan, kemampuan membaca.

How to Cite: Zulaikah, A. (2021). PPenggunaan Know What Learned (K-W-L) Strategy Untuk Meningkatkan Kemampuan Siswa Membaca Report Text. Jurnal Lingkar Mutu Pendidikan, 18 (1), 114-122. https://doi.org/10.54124/jlmp.v18i1.6

\section{Kata kunci. PENDAHULUAN}

Bahasa asing atau bahasa internasional di Indonesia salah satunya adalah Bahasa Inggris. Seiring perkembangan dan tuntutan jaman kompetensi dan performa tentang bahasa Inggris menjadi sebuah keharusan, terutama dalam dunia pendidikan, termasuk di pendidikan tingkat sekolah menengah atas. Pengajaran tentang membaca menjadi bagian dalam kurikulum 2013. Akan tetapi pola pengajarannya dilakukan secara integratif. 
Membaca merupakan salah satu kemampuan yang ada pada mata pelajaran Bahasa Inggirs dan suatu hal yang panting dalam proses pembelajaran. (Abidin, Mulyati and Yunasah 2018, 160) dijelaskan bahwa keterampilan berbahasa membaca juga merupakan suatu kebutuhan bagi kita. Membaca memiliki makna menjadikan peserta didik literat terhadap suatu konteks. Membaca ditafsirkan sebagai usaha memahami, menggunakan, merefleksi, dan melibatkan diri pada berbagai jenis teks dalam rangka mencapai suatu tujuan, yakni mengembangkan pengetahuan dan potensi.

Kesimpulan dari pendapat ahli tersebut bahwa membaca adalah proses kegiatan atau kognitif yang berupaya untuk menemukan berbagai informasi yang terdapat dalam tulisan. Proses berpikir untuk memahami isi teks yang dibaca merupakan makna membaca. Membaca berguna dalam kehidupan sehari-hari karena dengan membaca masyarakat dapat mengetahui hal yang baru.

Pentingnya membaca membuat guru menggunakan metode, pendekatan atau strategi untuk mengajarkan kemampuan membaca tersebut. Oleh karena itu guru menggunakan strategi Know What Learned (K W-L\}.

Penggunaan strategi K-W-L ini didasarkan pada penelitian sebelumnyayang sudah dilakukan oleh peneliti lain. (Magdalena, Cempaka and Azhar 2020,399) dalam penelitiannya tentang pembelajaran membaca intensif, guru hendaknya menerapkan strategi K-W-L karena penerapan strategi ini dapat mengingat kembali hal yang diketahui sesuai dengan pengetahuan awal siswa tentunya bersifat membantu siswa, serta menumbuhkan rasa ingin tahu siswa dengan bertanya mengenai hal yang ingin diketahui dari topik yang diberikan dan menambah wawasan siswa mengenai topik tersebut. Dengan demikian strategi K-W-L membantu siswa untuk termotivasi membaca artikel atau wacana karena dari pertanyaan yang telah dibuat siswa itu sendiri membuat siswa tertarik untuk menemukan jawaban dengan cara membaca secara intensif wacana atau artikel tersebut. (Satrijono, Badriyah and Hutama 2019, 107)

Proses yang dapat meningkatkan hasil belajar membaca pemahaman siswa, dapat menggunakan penerapan strategi pembelajaran know, want to know, and learned (K-W-L)

Dari kedua penelitian terkait tersebut masih tertumpu pada aspek membaca. Namun demikian penelitian ini berupaya untuk mengetahui dan menjelaskan tentang peningkatan kemampuan membaca siswaSMA kelas XI menggunakan strategi K-W-L untuk memiliki keterampilan membaca dalam mata pelajaran bahasa Inggris yaitu memahami teks yang dibaca.K-W-L adalah sebuah strategi pengajaran yang diperkenalkan oleh Donna Ogle.

Strategi ini berguna untuk membuat siswa aktif dalam pembelajaran. Guru akan mengunakan strategi K-W-L untuk mengajarkan teks ilmiah atau report text. Teks ini dipelajari siswa SMA kelas XI yang sudah dapat memulai untuk berpikir lebih kompleks. Tujuan dari penggunanan strategi pembelajaran K-W-L adalah mendorong siswa untuk aktif dalam berdiskusi di sebuah kelompok dan memahami maksud dari teks yang diberikan oleh guru. Bekerja dalam sebuah kelompok memberikan kesempatan kepada siswa untuk saling membantu dalam memahami teks secara keseluruhan. Harapannya kegiatan belajar menjadi lebih menarik dan merangsang siswa untuk senang membaca teks di kelas.

Berdasarkan latar belakang di atas maka permasalahan dalam penelitian ini dapat dirumuskan sebagai berikut, "Apakah dengan menggunakan strategi K-W-L dapat meningkatkan hasil belajar bahasa Inggris aspek membaca teks ilmiah pada siswa kelas XI IPA 1 di SMA Negeri 57 Jakarta?

Penelitian ini juga bertujuan untuk meningkatkan Aspek Membaca siswa pada teks ilmiah dengan Strategi $K-W$ - L sehingga dapat meningkat Hasil Belajar Bahasa Inggris melebihi KKM yang sudah ditetapkan yaitu 75 .

Manfaat penelitian ini bagi siswa dapat meningkatkan kemampuan membaca teks ilmiah, bagi guru dapat pengalaman langsung bagaimana penggunaan strategi K-W-L, bagi sekolah dapat memberikan masukan untuk mengambil kebijakan sebagai upaya peningkatan kualitas pembelajaran melalui pemenuhan berbagai strategi pembelajaran yang dianggap relevan dengan siswa dan karakteristik pembelajaran.

Teknik K-W-L ada tiga langkah, yaitu kegiatan pertama, merupakan bagian saran/ide sebelum kegiatan membaca dilaksanakan, jadi masih merupakan ide dari sebuah topik bacaan, apa yang siswa ketahui (K). Kegiatan kedua dengan membuat sejumlah pertanyaan, guru menuntut siswa menyusun 
tujuan khusus membaca, dalam artian apa yang siswa ingin pelajari dari sebuah bacaan tersebut (W). Kegiatan terakhir (I), siswa membaca dan menjawab pertanyaan yang mereka buat.

Sehingga setelah mengikuti kegiatan atau teknik ini, kemampuan memahami bacaan akan meningkat dari sebelumnya. Tujuan dasar membaca adalah untuk mendapatkan informasi sebanyak-banyaknya dan secepat mungkin dari teks tertulis. Membaca sebaiknya dilakukan secara efisien. Ini berarti membaca harus dilakukan dengan cara yang benar, dan dalam waktu yang efektif.

Strategi membaca ada beberapa diantaranya skimming, scanning, reading aloud dan uninterrupted sustained silent reading. Melalui skimming, dapat memperoleh kesimpulan makna keseluruhan teks secara umum oleh karena itu pembaca dapat membaca cepat. Skimming dapat membantu 3-4 kali lebih cepat dari membaca biasa. Langkah dalam melakukan skimming diantaranya baca dari judul dan sub judul dari sebuah buku untuk mengetahui ide utama yang dibahas, baca bagian awal dan akhir kalimat dari setiap paragraph, dan baca dengan teliti paragraf akhir yang biasanya berisi kesimpulan.

Perhatikan juga ilustrasi seperti gambar atau foto kalau ada, untuk memudahkan memahami isi bacaan lebih jauh dan berhenti sejenak untuk memahami isi tulisan tersebut. (Putra 2020) berbeda dengan skimming yang bertujuan untuk mencari gagasan atau inti utama dari sebuah bacaan.

Teknik membaca scanning bertujuan untuk menemukan informasi yang lebih spesifik dari sebuah bacaan yang panjang. Langkah melakukan scanning di antaranya dengan cara mencari kata kunci yang terdapat di dalam bacaaan. Selanjutnya menganalisis bacaannya sehingga menghasilkan sebuah simpulan dari bacaan atau teks. Scanning, pembaca dengan cepat dapat memperhatikan kata-kata tertentu atau melewati kata- kata tertentu yang dianggap tidak terlalu penting untuk memperoleh pemahaman informasi dariteks yang dibaca.

Reading aloud diperlukan untuk membantu siswa suka membaca dan fokus dalam bacaannya. Read aloud berasal dari read yang artinya membaca dan aloud yang artinya nyaring. Read aloud telah lama berkembang di negara-negara maju dan mengalami penyempurnaan dari waktu ke waktu.

Membaca senyap berkesinambungan atau Uninterrupted Sustained Silent Reading dapat menolong siswa untuk meningkatkan kemampuan membaca karena mereka membaca senyap dan tanpa gangguan jadi mereka bisa konsentrasi dalam membaca (Riska 2017)

Membaca difokuskan pada report text atau teks ilmiah. Report text merupakan sebuah teks yang menghadirkan informasi tentang suatu hal secara apa adanya. Jenis teks ini memang ada kesamaan dengan descriptive text yang sama-sama memberikan gambaran secara langsung tentang seseorang atau suatu benda (https://www.wallstreetenglish.co.id, 2020). Jika dalam descriptive text menggambarkan sesuatu secara spesifik seperti warna, style atau nama, Report text lebih menggambarkan sesuatu secara umum. Seperti: bagian-bagian, kekuatan, fungsi, atau juga sifat umum lainnya dari sesuatu yang ingin dibicarakan .Tata bahasa yang digunakan adalah simple present tense. Biasanya, tidak jarang pula penulis menambahkan simple passive voice sebagai variasi bentuk kalimat.

\section{METODE PENELITIAN}

Metode penelitian ini adalah penelitian kualitatif dengan desain Classroom Action Research (CAR). Penelitian Tindakan Kelas (PTK) adalah penelitian oleh guru yang dilakukan di kelasnya sendiri dengan tujuan untuk memperbaiki kinerjanya sehingga hasil belajar siswa meningkat melalui refleksi diri.

(Aqib, Penelitian Tindakan Kelas (PTK) TK/RA, SLB/SDLB 2017) langkah-langkah dalam Penelitian Tindakan kelas (PTK) merupakan satu daur atau siklus yang terdiri dari: 1) Merencanakan; 2) perbaikan; 3) Melaksanakan Tindakan; 4) Mengamati; dan 4) Melakukan Refleksi.

Penelitian ini dilaksanakan pada semester genap tahun ajaran 2018/2019 di kelas XI IPA 1, SMA Negeri 57 Jakarta, dengan jumlah siswa 36 yang terdiri dari 13 siswa laki-laki, 23 siswa perempuan, alasan penetapan pengambilan sampel di kelas XI IPA 1, karena kelas ini banyak siswa yang potensial dalam aspek membaca tetapi belum maksimal dalam pengarahan.

Dua teknik dalam mengevaluasi pembelajaran peserta didik di sekolah dikemukakan (Sujiono 2015, 
65) sebagai berikut: (1) Teknik tes Tes adalah cara (yang dapat dipergunakan) atau prosedur (yang perlu ditempuh) dalam rangka pengukuran dan penilaian di bidang pendidikan, yang berbentuk pemberian tugas atau serangkaian tugas sehingga dapat dihasilkan nilai yang melambangkan tingkah laku atau prestasi tes; (2) Teknik non-tes penilaian atau evaluasi hasil belajar peserta didik dilakukan dengan tanpa menguji peserta didik, melainkan dengan melakukan pengamatan secara sistematis (observation), melakukan wawancara (interview), menyebarkan angket (questionnare), dan memeriksa atau meneliti dokumen (documentary analysis).

Teknik pengumpulan data dalam penelitian iniadalahtes dan nontes. Tes berupa tes tulis sedangkan non tes berupa lembar observasi dan tes K-W-L. Tes dipergunakan untuk mendapatkan data tentang hasil belajar siswa dalam mata pelajaran bahasa Inggris. Observasi atau pengamatan dipergunakan untuk mengumpulkan data tentang keaktifan siswa di kelas.

Tujuan dari tes adalah untuk mengetahui ketuntasan belajar siswa secara individual maupun secara klasikal, untuk mengetahui letak kesalahan-kesalahan yang dilakukan siswa sehingga dimana kelemahannya siswa dapat di lihat, khususnya pada pokok bahasan materi ajar yang belum tercapai. Metode observasi (pengamatan) digunakan untuk memperkuat data yang dikumpulkan, oleh ternan sejawat untuk mengetahui dan merekam aktifitas guru dan siswa dalam proses belajar mengajar.

Perlu diadakan analisis data untuk mengetahui keefektifan suatu strategi dalam kegiatan pembelajaran. Pada penelitian ini menggunakan teknik analisis deskriptif kualitatif, yaitu suatu model penelitian sesuai dengan data yang diperoleh yang bersifat menggambarkan kenyataan atau fakta. Tujuannya untuk memperoleh respon siswa terhadap kegiatan pembelajaran serta aktivitas siswa selama proses pembelajaran untuk mengetahui prestasi belajar yang dicapai siswa.

Metode panelitian ini menggunakan metode deskriptif kualitatif. Metode deskriptif adalah melukiskan, mengambarkan, atau memaparkan keadaan objek yang diteliti sebagai apa adanya, sesuai dengan situasi dan kondisi ketika penelitan tersebut dilakukan.

Penelitian ini juga menggunakan pendekatan kualitatif. Pendekatan kualitatif adalah berpedoman penilaian subjektif nonstatistik atau nonmatematis dengan Presentase keberhasilan siswa setelah proses belajar mengajar setiap putarannya dilakukan dengan menganalisis tingkat keberhasilan atau memberikan evaluasi berupa soal tes tertulis pada setiap akhir putaran/siklus.

Langkah-langkah penelitian ini sebagai berikut pada tahapan, planning: penulis telah membuat persiapan sebelumnya yaitu mempersiapkan Silabus, RPP, bahan ajar, soal tes tulis pada siklus I, K-W-L chart, daftar hadir, catatan lapangan dan lembaran observer kegiatan siswa, lembar observer kegiatan guru dan teman sejawat sebagai observer. Selama proses berlangsung observer diminta untuk membantu kegiatan proses belajar mengajar mengabadikannya dengan kamera.

Pada tahapan acting pelaksanaan/tindakan: pelaksanaan penelitian berlangsung dalam beberapa siklus tergantung dari pencapaian indikator keberhasilan. Siklus bisa dihentikan apabila indikator keberhasilan telah dicapai. Tiap siklus diawali dengan pedahuluan, kegiatan intidan penutup.

Pada tahap observing: dengan mencatat aktifitas siswa selamaproses belajarmengaj ar didalamkelas yang dituangkan dalam catatan lapangan. Mengamati dan mencatat keaktifan peserta didik selama proses mekanisme kerja penelitian yang dimana ukuran nilai yang digunakan dalam penelitian ini bukanlah angka-angka skor, melainkan kategorisasi nilai atau kualitasnya, pembelajaran berlangsung menggunakan format observasi yang sudah disiapkan, dan juga mendokumentasikan kegiatan yang berlangsung.

Pada tahap reflecting: pengkajian ulang atas proses pembelajaran yang telah terjadi dan segala hal yang muncul dari proses tersebut. Pelaksanaan refleksi ini dilakukan oleh peneliti dan observer (pengamat). Tujuan untuk membahas dan memberikan solusi atas permasalahan yang terjadi dan menentukan tindakan apa yang akan diberikan kepada siswa agar permasalahan tersebut tidak terjadi lagi dari hasil refleksi siklus I, digunakan untuk menentukan tindakan di siklus II. Kekurangan dan permasalahan di siklus I diperbaiki dan kelebihannya dipertahankan sehingga dapat terjadi peningkatan dalam membaca teks ilmiah.

Teknik pengolahan data; Data dikumpulkan pada setiap siklus dan dianalisis secara deskriptif dengan menggunakan teknik persentasi. Hasil belajar dianalisis melalui nilai rata-rata ulangan harian, daya serap, ketuntasan belajar. Masing-masing dibandingkan dengan nilai sebelumnya 
dan Kriteria Ketuntasan Minimal (KKM). Data aktifitas siswa dalam pembelajaran dengan menganalisis tingkat keaktifan siswa dalam pembelajaran Indikator keberhasilan hasil belajar angkanya lebih besar atau sama dengan 75 baru dikatakan tuntas.

Hasil belajar siswa dapat meningkat dengan menggunakan strategi pembelajaran K-W-L. Hasildari kedua siklus inididukung oleh data hasil pengamatan selama proses penelitian berlangsung.

\section{HASIL DAN PEMBAHASAN}

Sebelum pelaksanaan penelitian dilakukan Pratindakan berupa penilaian tertulis untuk memperoleh data awal tentang hasil belajar membaca siswa di kelas XI IPA 1SMA Negeri 57 Jakarta. Hasil penilaian tertulis menunjukkan 55,55\% (20 orang) Kurang, 19,44\% (7 orang) Cukup, 19,44\% (7 orang) Baik, 5,55\% (2 orang) Sangat Baik. Berdasarkan hasil tersebut perlu dilakukan tindakan perbaikan dalam pembelajaran.

Planning; siklus 1 berlangsung dua kali pertemuan. Siswa dibagi menjadi 6 kelompok. Setiap kelompok jumlah anggotanya 5 - 6 orang. Materi pelajaran: Membaca Teks IImiah/Report text disampaikan dengan strategi pembelajaran K-W-L. Pembelajaran dibagi menjadi tiga tahap yaitu pembukaan, kegiatan inti, dan penutup. Pembelajaran dimulai dengan menyampaikan tujuan pembelajaran, mengkomunikasikan kompetensi dasar yang akan dicapai serta memotivasi siswa.

Pada saat pelaksanaan kegiatan intiguru menyampaikan informasi tentang pentingnya Membaca Teks Ilmiah/Report Teks, kemudian dilanjutkan dengan menginformasikan kegunaan K-W-L dan memberikan judul wacana. Masing-masing kelompok menganalisa judul yang telah diberikan oleh guru dengan menggunakan K-W-L. Tiap kelompok berdiskusi untuk mengisi kolom yang pertama yaitu kolom K (Know). Pada kolom ini, siswa diminta untuk menuliskan apa yang merekaketahuitentang judul tersebut. Misalnya judulnya tentang "Tiger". Informasi yang siswa ketahui diantaranya adalah "Tiger is a wild animal". Waktu yang disediakan untuk kelompok mengisi kolom yang pertama adalah 5 menit.

Kemudian dilanjutkan dengan mengisi kolom keduayaitu W (What), pada kolom ini siswa diminta untuk membuat pertanyaan dengan menggunakan $5 \mathrm{~W} 1 \mathrm{H}$. Contohnya siswa tidak mengetahui berat bayi macan, maka siswa tersebut bisa menulis di kolom W dengan pertanyaan "What is the weight of tiger's baby?" Waktu yang disediakan untuk kelompok mengisi kolom yang kedua adalah 5 menit.

Kolom ketiga yaitu L (learn) diisi setelah guru membagikan lembaran kertas yang berisi teks ilmiah/report text tentang judul yang sudah diberikan sebelumnya. Siswa diminta untuk mencari jawaban dari pertanyaan yang sudah mereka tulis di kolom W dan menjawabnya di kolom L dengan membaca teks ilmiah/report text tersebut. Waktu yang disediakan untuk kelompok mengisi kolom yang ketiga adalah 5 menit.

Setelah waktu habis guru mengingatkan siswa mempresentasikan hasil diskusinya. Waktu yang disediakan 10 menit. Setelah proses ini selesai secara bergantian setiap kelompok mempresentasikan hasil diskusinya dihadapan teman-temannya. Waktu presentasi selesai masingmasing kelompok diberi waktu untuk bertanya, memberikan sanggahan atau mengemukakan pendapatnya. Hal ini berguna untuk melatih siswa belajar secara aktif dan menyempurnakan hasil diskusi tersebut.

Dalam pelaksanaan proses pembelajaran ini peneliti dibantu oleh seorang ternan guru sebagai observer untuk memantau semua kegiatan siswa maupun guru selama pembelajaran berlangsung. Guru memberikan tes tulis setelah melakukan dua kali pertemuan.

Observasi siklus I, guru dan observer mengamati jalannya proses pembelajaran menggunakan strategi K-W-L. Masih ada siswa yang mengobrol saat guru menerangkan. Pembagian tugas dikelompok masih belum rata, siswa kelompok bawah masih belum berperan aktif.

Hasil observasi menunjukkan kerja sama dalam kelompok, keaktifan dalam kelompok, mengajukan pertanyaan, memberikan jawaban dan menyampaikan pendapat, dalam belajar masih kurang ratarata 2,57 atau 51,4\% saja dari keseluruhan siswa. Hal ini disebabkan siswa masih belum terbiasa belajar dengan strategi pembelajaran menggunakan K-W-L. Mereka masih ragu-ragu dalam membuat pertanyaan yang berkaitan dengan judul yang sudah diberikan guru dan belum bisa bekerja sama dalam kelompok yang baru. Hal ini disebabkan oleh kebiasaan siswa selama ini melakukan 
aktifitas hanya dengan ternan yang mereka kenal dengan baik, sehingga terlihat kerjasama dalam kelompok masih sangat sedikit dan bersifat individual. Berdasarkan hal tersebut, perlu adanya perbaikan di siklus berikutnya. Untuk aktifitas pengelolaan kelas, dalam kegiatan pendahuluan guru menyampaikan tujuan pembelajaran dengan cukup (60\%) tetapi mengaitkan pembelajaran sekarang dengan yang terdahulu serta memotivasi siswa masih kurang (60\%).

Pada kegiatan inti terlihat guru cukup bisa membimbing siswa belajar dalam kelompok terbukti hanya $40 \%$ siswa yang bisa menyampaikan pendapatnya termasuk $60 \%$ yang mengajukan dan menjawab pertanyaan. Kegiatan penutup belum sesuai dengan yang diharapkan baru $60 \%$, begitu juga suasana kelas guru yang antusias (60\%\} sementara murid masih pasif (40\%). Untuk hasil tes siklus I, peserta didik yang memperoleh nilai Sangat Baik 4 orang $(11,11 \%)$, Baik 10 orang $(27,77 \% \%$, Cukup 10 orang $(27,77 \%\}$, Kurang 12 orang $(33,33 \%$ \}. Untuk kriteria ketuntasan belajar siswa hanya $66,65 \%$ (24 orang) yang mendapat nilai diatas 74 .

Refleksi: Tahapan ini mendiskusikan dengan observer dapat diketahui bahwa hasil belajar siswa pada siklus I berdasarkan hasiltesnya menunjukkan hasil yang belum memuaskan, maka perlu usaha yang sungguh-sungguh baik oleh guru maupun siswa. Hasil observasi yang dilakukan oleh observer maupun peneliti belum sesuai dengan yang diharapkan, yaitu siswa belum mampu memperoleh keterampilan membaca sesuai dengan apa yang ingin diwujudkan oleh strategi pembelajaran dengan menggunakan K-W-L. Aktifitas guru dalam pengelolaan pembelajaran pada umumnya masih kurang, untuk itu pengelolaan pembelajaran pada siklus berikutnya perlu ditingkatkan. Untuk itu perlu ada perbaikan di siklus II.

Planning pada siklus II: guru melakukan perubahan dengan memperkuat strategi pembelajaran hari itu yaitu strategi pembelajaran dengan menggunakan $K-W-L$ dengan menjelaskan kegunaannya dengan detail. Siswa duduk dalam kelompok masing-masing. Sebelum diskusi kelompok dimulai guru terlebih dahulu memberikan penjelasan tentang tujuan pembelajaran dan mengaitkan pembelajaran terdahulu dengan pembelajaran sekarang. Pelaksanaan proses pembelajaran pada siklus II sama halnya dengan siklus I yang terdiri dari tiga tahap yaitu, Pembukaan, Kegiatan Inti dan Penutup. Pada siklus II ini guru mengingatkan siswa bahwa setiap tahap mengisi kolom K-W-L mereka berdiskusi dengan temannya dan menganalisa judulyang sudah diberikan oleh guru.

Acting: Guru membentuk kelompok sebanyak 6 dan tiap kelompok terdiridari 6 siswa. Guru menuliskan sebuah judul dari teks ilmiah. Masing masing kelompok menganalisa judulyang telah diberikan oleh guru dengan menggunakan $K$ - $W$ - $L$ chart. Tiap kelompok berdiskusi untuk mengisikolom yang pertama yaitu kolom K (Know). Pada kolom ini, siswa diminta untuk menuliskan apa yang mereka ketahui tentang judul tersebut. Misalnya judulnya tentang "Cheetah." Informasi yang siswa ketahui diantaranya adalah "Cheetahis a wild animal'. Waktu yang disediakan untuk kelompok mengisi kolom yang pertama adalah 5 menit.

Kemudian dilanjutkan dengan mengisi kolom kedua yaitu W (What), pada kolom ini siswa diminta untuk membuat pertanyaan dengan menggunakan $5 \mathrm{~W} 1 \mathrm{H}$. Contohnya siswa tidak mengetahui berat bayi macan, maka siswa tersebut bisa menulis di kolom W dengan pertanyaan "What is the weight of cheetah's baby?" Waktu yang disediakan untuk kelompok mengisi kolom yang kedua adalah 5 menit.

Kolom ketiga yaitu L (Learn) diisi setelah guru membagikan handout lembaran kertas yang berisi teks ilmiah/report text tentang judul yang sudah diberikan sebelumnya. Siswa diminta untuk mencari jawaban dari pertanyaan yang sudah mereka tulis di kolom $\mathrm{W}$ dan menjawabnya di kolom $\mathrm{L}$ dengan membaca teks ilmiah/report text tersebut. Waktu yang disediakan untuk kelompok mengisi kolom yang ketiga adalah 5 menit.

Setelah waktu habis guru mengingatkan siswa mempresentasikan hasil diskusinya. Waktu yang disediakan 10 menit. Setelah proses ini selesai secara bergantian setiap kelompok mempresentasikan hasil diskusinya dihadapan teman-temannya. Waktu presentasi selesai masing masing kelompok diberi waktu untuk bertanya, memberikan sanggahan atau mengemukakan pendapatnya. Hal ini berguna untuk melatih siswa belajar secara aktif dan menyempurnakan hasil diskusi tersebut. Pada siklus IIini guru lebih aktif memfasilitasi siswa yang menemukan hambatan dalam memahami teks ilmiah tersebut.

Dalam pelaksanaan proses pembelajaran ini penulis dibantu oleh seorang ternan guru sebagai observer untuk membantu memantau semua kegiatan siswa maupun guru selama pembelajaran berlangsung. Guru memberikan tes tulis setelah melakukan dua kali pertemuan. 
Observasi siklus II, guru dan observer mengamati jalannya proses pembelajaran menggunakan K-W-L.Tidak ada siswa yang mengobrol saat guru menerangkan. Pembagian tugas dikelompok sudah terdistribusi secara merata, siswa kelompok bawah telah menunjukkan peran aktif.

Hasilobservasi menunjukkan kerja sama dalam kelompok, keaktifan dalam kelompok, mengajukan pertanyaan, memberikan jawaban dan menyampaikan pendapat, adanya peningkatan aktifitas siswa dalam proses pembelajaran, misalnya indikator satu tentang kerjasama dalam kelompok, pada siklus II mencapai $78,6 \%$ siswa sudah bisa bekerjasama. Secara umumaktifitas siswa meningkat menjadi $77.4 \%$. Untuk aktifitas pengelolaan kelas, hasil observasi terhadap aktifitas guru dalam pengeloaan pembelajaran pada siklus II masuk ketegori baik yaitu 90,00\%.

Dalam kegiatan pendahuluan guru menyampaikan tujuan pembelajaran dengan sangat baik (93\%) denganmengaitkan pembelajaran sekarang dengan yang terdahulu sertamemotivasi siswa sangat baik.

Pada kegiatan inti terlihat guru cukup bisa membimbing siswa belajar dalam kelompok terbukti hanya $85 \%$ siswa yang bisa menyampaikan pendapatnya termasuk $74 \%$ yang mengajukan dan menjawab pertanyaan. Kegiatan penutup sesuai dengan yang diharapkan yaitu $100 \%$. Untuk hasil tes siklus II, ada peningkatan hasil belajar siswa yaitu Sangat Baik 10 orang $(27,77 \%)$, Baik 14 orang $(38,88 \%)$, Cukup 8 orang $(22,22 \%)$ dan Kurang 4 orang (11,11\%). Untuk kriteria ketuntasan sudah $88,87 \%$ (32 orang) yang mendapat nilai di atas 74 .

Refleksi dari siklus II: Setelah pelaksanaan siklus II, dilakukan refleksi terhadap hasil pembelajaran. Hasil belajar siswa pada siklus II sudah memuaskan karena siswa sudah maksimal memanfaatkan waktu yang disediakan guru untuk menganalisa bacaan teks ilmiah/report text dengan strategi pembelajaran menggunakan K-W-L pada Kompetensi Dasar: Menerapkan fungsi sosial, struktur teks, dan unsur kebahasaan teks. interaksi transaksional lisan dan tulis yang melibatkan tindakan memberi dan meminta informasi terkait keadaan/tindakan/kegiatan/ kejadian tanpa perlu menyebutkan pelakunya dalam teks ilmiah, sesuai dengan konteks penggunaannya. (Perhatikan unsur kebahasaan passive voice), guru juga terlihat sangat aktif memberikan informasi.

Aktifitas siswa pada siklus II menunjukkan peningkatan yang baik terutama bekerjasama dalam kelompok, demikianjuga dengan membacateks ilmiah/report teks dengan menggunakan strategi $\mathrm{K}-\mathrm{W}-\mathrm{L}$, kemampuan bertanya dan mengemukakan pendapat. Aktifitas guru dalam pengelolaan pembelajaran pada siklus II menunjukan peningkatan yang baik.

Peningkatan hasil belajar bahasa Inggris hasil siklus Idan II, disajikan dalam tabel berikut ini:

Tabel 1. Perbandingan Persentase Hasil Belajar Siswa pada siklus I,II

\begin{tabular}{ccccc}
\hline No & Nilai & Siklusl & Siklus II & Perbedaan \\
\hline 1 & $92-100$ & $11,11 \%$ & $22,22 \%$ & $11,11 \%$ \\
2 & $84-91$ & $27,77 \%$ & $22,77 \%$ & $0 \%$ \\
3 & $75-83$ & $27,77 \%$ & $33,33 \%$ & $-5,56 \%$ \\
4 & 74 & $33,33 \%$ & $16,66 \%$ & $-16,67 \%$ \\
\hline & KKM & $66,65 \%$ & $83,32 \%$ & Tuntas \\
\hline
\end{tabular}

Berdasarkan data di atas, secara umum menunjukkan hasil belajar siswa mengalami peningkatan. Hal ini terlihat pada tabel nilai 90-100 (Sangat Baik) mengalami kenaikan sebanyak 11,11\%, sedangkan nilai 74 (Kurang) mengalami penurunan 16,67\%. Sementara itu Kriteria Ketuntasan Minimal dari siklus I dari 66,65\% naik menjadi 83,32\% pada siklus II.

Peningkatan aktivitas belajar siswa setelah dilaksanakan strategi pembelajaran dengan menggunakan K-W-L chart dapat dilihat dari tabel 2 berikut. 
Tabel 2. Persentase Peningkatan aktifitas siswa pada Siklus I dan II

\begin{tabular}{|c|c|c|c|c|}
\hline No & Indikator Perbedaan & Siklus I & Siklus II & \\
\hline 1 & Kerjasama dalam kelompok & 45,6 & 78.8 & 33,2 \\
\hline 2 & Keaktifan siswa & 51.4 & 81,0 & 29,6 \\
\hline 3 & Mengajukan pertanyaan & 48,4 & 74.2 & 25,8 \\
\hline 4 & Memberikan jawaban & 45,6 & 73.0 & 27,4 \\
\hline \multirow[t]{2}{*}{5} & Menyampaikan pendapat & 48,0 & 85,0 & 37.0 \\
\hline & Rata-rata & 47,8 & 78.4 & 30.6 \\
\hline
\end{tabular}

Berdasarkan data di dalam tabel 2 di atas yang merupakan hasil perbandingan prosentase aktifitas siswa menunjukan peningkatan yang signifikan dari siklus I sampai siklus II. Kerjasama dalam kelompok naik 33,2\%, keaktifan naik 29,6\%, mengajukan pertanyaan naik 25,8\%, memberikan jawaban naik $27,4 \%$, menyampaikan pendapat naik $37.0 \%$ dan rata-rata keseluruhan indikator aktifitas siswa naik 30.6\%.

Peningkatan aktifitas guru dari siklus I dan II dapat dilihat pada tabel 3 berikut ini:

Tabel 3. Perbandingan aktivitas guru padasiklus Idan II

\begin{tabular}{llll}
\hline Aspek yang dinilai & Siklus I & Siklus II & Perbedaan \\
\hline Aktivitas Guru & $60 \%$ & $90 \%$ & $30 \%$ \\
\hline
\end{tabular}

Merujuk pada data dalam Tabel 3 di atas dapat diambil kesimpulan bahwa pada setiap isiklus terjadi peningkatan aktifitas guru, yaitu perbedaannya 30\% hal ini disebabkan oleh guru selalu belajar dari pengalaman pada siklus sebelumnya tentang kekurangan-kekurangan cara menyampaikan pembelajaran, dan berusaha memperbaikinya pada siklus berikutnya.

Melihat kenyataan hasil belajar siswa diatas yang mengalami kenaikan KKM dari kondisi awal dan Siklus 1 sejumlah 66,65\% dari jumlah siswa menjadi 83,32\% pada Siklus ke II, memperlihatkan bahwa pada Kompetensi Dasar: Menerapkan fungsi sosial, struktur teks, dan unsur kebahasaan teks interaksi transaksional lisan dan tulis yang melibatkan tindakan memberi dan meminta informasi terkait keadaan/tindakan/kegiatan/kejadian tanpa perlu menyebutkan pelakunya dalam teks ilmiah, sesuai dengan konteks penggunaannya. (Perhatikan unsur kebahasaan (passive voice), dengan menerapkan strategi pembelajaran dengan menggunakan K-W-Lsangat efektif.

Kesuksesan penerapan strategi pembelajaran dengan menggunakan $\quad \mathrm{K}-\mathrm{W}$-L dalam peningkatan hasil belajar siswa,juga diiringi dengan perbaikan aktifitas siswa dan aktifitas guru dalam pengelolaan pembelajaran. Riset ini selaras pula dengan penelitian (Jewaru, Simpen and Dhanawaty 2020,62) yang menjelaskan bahwa keberhasilan penerapan strategi KWL dalam meningkatkan kemampuan membaca pemahaman siswa sangat ditentukan oleh langkah-langkah atau faktor-faktor strategi KWL seperti pengetahuan awal yang dimiliki, perumusan tujuan khusus membaca, dan pemahaman tehadap informasi yang diperoleh dari teks.

Penelitian (Usman, Fata and Pratiwi2018, 41) menjelaskan bahwa

"...in general, the study concludes that the KWL strategy could increase the students' reading ability. The strategy could be properly applied in reading class skill since it helped the teachers to engage students in a group work. However, it is suggested that the teachers choose topics suitable for their lesson material so that the KWL strategy can work properly, allowing the students to discuss about familiar issues."

Strategi pembelajaran menggunakan K-W-L membantu siswa untuk meningkatkan pemahaman terhadap sebuah teks dengan baik.

\section{SIMPULAN DAN SARAN}

Penelitian ini bertujuan menjawab permasalahan yang diajukan pada bagian terdahulu, yaitu mengemukakan secara jelas tentang peningkatan hasil belajar membaca siswa kelas XI pada report 
text. Berdasarkan hasil penelitian dan pembahasan menunjukkan bahwa terdapat peningkatan secara gradual dari tingkat menengah ke atas menuju ketuntasan sesuai target KKM. Hal tersebut di atas dapat dilihat dari nilai tes siklus I 74,17 dengan jumlah siswa yang tuntas sebanyak $66,65 \%$ sedangkan pada siklus II diperoleh nilai rata-rata 83,06 dengan jumlah siswa yang tuntas sebanyak $83,32 \%$, berarti terjadi kenaikan sebesar 16,41 point dan ketuntasan sebesar 16,67\%.

Prosentase ketercapaian siswa signifikan dalam membaca teks report dalam kegiatan pembelajaran dari siklus I dibandingkan siklus II. Strategi K W-L sangat tepat untuk menghasilkan hasil belajar yang sangat baik, karena kerjasama dalam kelompok kelompok kecil secara kolaboratif dalam menganalisa judul yang diberikan oleh guru.

Strategi K-W-Ldapat digunakan secara terus-menerus, karena benarbenar mampu meningkatkan Hasil belajar bahasa Inggris pada aspek membaca. Dengan menggunakan strategi ini memotivasi siswa untuk membaca teks bahasa Inggris.

Berdasarkan hasil penelitian dan pembahasan dapat disimpulkan bahwa pembelajaran menggunakan strtegi Know What Learned (K-W-L) dapat meningkatkan kemampuan membaca teks, terutama dalam membaca teks laporan. Hasil penelitian ini masih memerlukan pengkajian secara mendalam dan meluas untuk kesempurnaan terutama pada tingkat sekolah menengah atas dan juga pada levelyang lebih tinggi.

Penelitian ini belum menjangkau semua aspek dan sekaligus menjadi keterbatasan penelitian ini, untuk itu diharapkan dapat melakukan penelitian lanjutan berdasarkan penelitian ini baik dari segi model pembelajaran, media, strategi, metode, kualitas dan lain sebagainya. Hal ini dilakukan dalam rangka meningkatkan kualitas praktik pengajaran di sekolah.dan pengembangan ilmu pengetahuan secara umum.

\section{PUSTAKA ACUAN}

In Pembelajaran Literasi: Meningkatkan Kemampuan Literasi Matematika, Sains, Membaca dan Menu/is, by Yunus Abidin, Tita Mulyati, \& Hana Yunasah, 160. Jakarta: Bumi Aksara, 2018.

In Penelitian Tindakan Kelas (PTK) TKIRA, SLB! SDLB, by ZainalAqib, 8-9. Yogyakarta: Ar-Ruzz Media, 2017.

https:/lwww.wallstreetenglish.co.id.September 3, 2020. https://www wallstreetengl ish.co.id/english-tips/penjelasan-report text/ (accessed Juli20, 2021).

Jewaru, Melita Eufrasia, I Wayan Simpen, and Ni Made Dhanawaty. "PENERAPAN STRATEGI KWL (KNOW, WANT TO KNOW, LEARNED) DALAM MENINGKATKAN KEMAMPUAN MEMBACA PEMAHAMAN SISWA KELAS VIII SMP BALI STAR ACADEMY TAHUN AJARAN 2019/2020." Jurnal Pendidikan Bahasa dan Sastra Indonesia, 2020.

Magdalena, Ina, Bunga Cempaka, and Cantika Rofiqoh Azhar. "MENINGKATKAN KEMAMPUAN MEMBACA MELALUI STRATEGI PEMBELAJARAN KNOW WANT LEARNED (KWL) SISWA 01 KELAS IV SON

PINANG 1." Jurnal Edukasi dan Sains, 2020:399.

Putra, Aditya Permana. https:llpahamify.com. April 7, 2020. https://pahamify.com/blog/skimming-dan-scanning-teknikmembacauntuk-persiapan-tps-utbk/ (accessedJuli20,2021).

Riska."' The Use of Sustained Silent Reading (SSR) Method to Improve Students Reading Comprehension at The Second Year Students of SMPN 3 SungguminasaGowa" [Thesis]." Sulawesi; AlauddinState Islamic University, 2017.

Satrijono, Hari, Izzah Fitri Badriyah, and Fajar Surya Hutama. "Penerapan Strategi Know, Want To Know, Learned (KWL) untuk Meningkatkan Hasil Belajar Membaca Pemahaman Siswa Kelas IVB Tema Indahnya Keragaman di Negeriku di SDN Jember Lor 02." Jurnal Profesi Keguruan, 2019: 107.

Sujiono, Anas. "Pengantar Evaluasi Pendidikan." 65. Jakarta: PT. Raja Grafindo Perkasa, 2015.

Usman, Bustami, Ika Apriani Fata, and Ratih Pratiwi. "TEACHING READING THROUGH KNOW-WANT-LEARNED (KWL) STRATEGY: The effects and benefits." Englisia, 2018: 41. 